\title{
DIAMETER STRUCTURE AND ITS RELATIONSHIP WITH FRUIT AND SEED PRODUCTION IN A NATIVE BRAZIL NUT GROVE IN MATO GROSSO
}

\author{
Helio Tonini ${ }^{1}$, Aisy Botega Baldoni ${ }^{2}$, Silvia de Carvalho Campos Botelho ${ }^{2}$ \\ ${ }^{1}$ Embrapa South livestock Sul, Bagé, RS, Brasil, helio.tonini@embrapa.br (AUTOR PARA CORRESPONDÊNCIA) \\ ${ }^{2}$ Embrapa Agrossilvipastoral, Sinop, MT, Brasil. Aisy.baldoni@embrapa.br. Silvia.campos@embrapa.br \\ Received for publication: 03/01/2019 - Accepted for publication: 22/04/2019
}

\begin{abstract}
Resumo
Estrutura diamétrica e a sua relação com a produção de frutos e sementes em um castanhal nativo em Mato Grosso. O estudo objetivou avaliar a variação anual da produção e produtividade de castanheiras-do-brasil e determinar a associação entre a estrutura diamétrica e a produção de frutos/sementes em uma floresta estacional semidecidual submetida à exploração madeireira no Mato Grosso, Brasil. Os dados foram coletados em duas parcelas permanentes $(300 \mathrm{~m} \times 300 \mathrm{~m})$ e todas as árvores $(n=279)$ com diâmetro à altura do peito (DAP) $\geq 10$ tiveram a produção monitorada de outubro a fevereiro durante cinco safras entre 2012 e 2017 . As associações entre peso seco de sementes (PSS) por árvore e DAP, posição e formato da copa e número de frutos foram estabelecidos usando a análise de regressão passo-a-passo. O modelo baseado na DAP foi um bom preditor e revelou que o PSS por árvore aumentou em $1,3 \mathrm{~kg}$ em média a cada $10 \mathrm{~cm}$ de aumento no DAP. As árvores atingiram a fase reprodutiva com DAP $<50 \mathrm{~cm}$ e suas características e valores médios de PSS foram: $10 \mathrm{~cm} \leq$ DAP $<30 \mathrm{~cm}$ - árvores dominadas/suprimidas/copas malformadas $\left(0,12 \mathrm{~kg}\right.$ árvore $^{-1}$ ano $\left.^{-1}\right) ; 30 \mathrm{~cm} \leq \mathrm{DAP}<70$ $\mathrm{cm}$ - árvores dominantes/co-dominantes/copas com boa forma (1,23 kg árvore ${ }^{-1}$ ano $\left.^{-1}\right) ; \mathrm{DAP} \geq 70 \mathrm{~cm}$ - árvores dominantes/ co-dominantes/copas bem formadas $\left(4,8 \mathrm{~kg}^{2}\right.$ arvore $\left.{ }^{-1} \mathrm{ano}^{-1}\right)$. O DAP explicou $34 \%$ da variação no PSS. Nossos resultados são importantes para o manejo sustentável, pois permitem a avaliação do rendimento atual e futuro das castanheiras objetivando a melhoria da economia das comunidades que dependem da floresta e de empresas associadas.

Palavras-chave: Bertholletia excelsa, produto florestal não madeireiro, prognose de produção de frutos/sementes.
\end{abstract}

\section{Abstract}

The study aimed to evaluate the annual variation in fruits and seed production and productivity of Brazil nut trees and to determine the association between diametrical structure and fruit/seed production in a semideciduous seasonal forest undergoing logging in Mato Grosso, Brazil. Data were collected in two permanent plots $(300 \mathrm{~m} \mathrm{x} 300 \mathrm{~m})$ and all trees $(n=279)$ with diameter at breast height $(\mathrm{DBH}) \geq 10 \mathrm{~cm}$ were monitored for fruit production from October to February during five harvest seasons between 2012 and 2017. Associations between seed dry weight (SDW) per tree and DBH, crown position and shape and fruit number were established using stepwise regression analysis. The model based on DBH was a good predictor of seed production and revealed that SDW tree-1 increased by $1.3 \mathrm{~kg}$ on average for every $10 \mathrm{~cm}$ increase in DBH. Trees reached the reproductive phase with DBH $<50 \mathrm{~cm}$. Characteristics and mean SDW values of the diameter classes were: 10

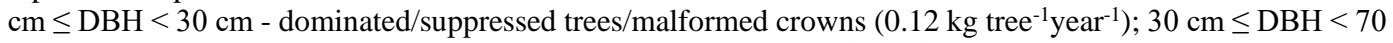
$\mathrm{cm}$ - dominant/co-dominant/good crown shape $\left(1.23 \mathrm{~kg}^{\text {tree }} \mathrm{year}^{-1}\right)$; DBH $\geq 70 \mathrm{~cm}$ - dominant/codominant/well-formed crowns $\left(4.8 \mathrm{~kg} \mathrm{tree}^{-1} \mathrm{year}^{-1}\right)$. DBH explained $34 \%$ of the variation in the mean SDW. Our results are important for the sustainable management of the study stands, allowing the assessment of current and future yields of Brazil nuts for the purpose of improving the economy of forest-dependent communities and associated enterprises.

Keywords: Bertholletiaexcelsa, non-timber forest product, predicting production of fruits/seeds.

\section{INTRODUCTION}

The diameter structure of a forest refers to the distribution of the total number of trees per hectare according to diameter classes. The concept is used in forest science to characterize floristic typologies, succession and conservation stages, ecological groups and management regimes, and in growth and production modeling (SOUZA; SOARES, 2013).

The population structure of native Brazil nut trees (Bertholletia excels Bonpl.) has been investigated in various regions of the Amazon Basin including those in Brazil (WADT et al., 2005; SALOMÃO, 2009; SCOLES; 
GRIBEL, 2011; NEVES et al., 2016), Bolivia (ZUIDEMA; BOOT, 2002; ZUIDEMA, 2003) and Peru (MOLLROCEK et al., 2014; ROCKWELL et al., 2017). However, only a small number of studies have attempted to establish a relationship between diameter structure and fruit or seed production (ZUIDEMA; BOOT, 2002; WADT et al., 2005; KAINER et al., 2007, TONINI; PEDROZO, 2014), and even fewer have analyzed data obtained over a protracted monitoring period (three to seven years) (ZUIDEMA; BOOT, 2002; KAINER et al. 2007, TONINI; PEDROZO, 2014).

Previous analyses of diameter distributions of native Brazil nut trees have shown that in closed forest areas, with low light incidence under the canopy and no history of recent disturbance, there is predominance of individuals of intermediate diameter classes with unimodal, but sometimes erratic, distribution (ZUIDEMA, 2003; SALOMÃO, 2009; SCOLES; GRIBEL, 2012). Various proposals have been put forward to explain this structure, including: (i) the anthropogenic hypothesis (THOMAS et al., 2015) in which the present forest configuration is believed to result from ancient cultivation by indigenous peoples; (ii) the dispersion hypothesis that assumes seeds are transported mainly over short distances by caviomorph rodents of the genus Dasyprocta; (iii) the seed bottleneck hypothesis in which the forest structure is considered to derive from a severe shortage of seeds caused by overharvesting; (iv) the mutualism bottleneck hypothesis in which a combination of factors (scarcity of seeds and pollinators) are presumed to be responsible for the forest pattern; and (v) the regeneration viability bottleneck hypothesis, which proposes that the forest structure results from the absence of clearings since B. excels develops better in large open areas and is enhanced during the initial growth stages (ZUIDEMA; BOOT, 2002; ZUIDEMA, 2003;SALOMÃ̃, 2009).

Vegetation physiognomy and the history of forest utilization may also influence the diameter structure of Brazil nut groves (WADT et al., 2005; SCOLES; GRIBEL, 2011). The rationale for this hypothesis is that forests located in the south and west of the Amazon are more susceptible to natural disturbance with the formation of natural gaps that promote regeneration of the species. However, in the dense forests of the central and northeastern regions of the Amazon, anthropogenic disturbance would have been the most important factor since the preColumbian era, and the effects were likely responsible for the grouped geographic distribution and the high densities and high mean diameters observed in Brazil nut stands located in these areas (THOMAS et al., 2015). Nevertheless, the recruitment of new individuals has commonly been observed in non-disturbed areas covered by dense forests (SALOMÃO et al., 2009; GUEDES et al., 2014; NEVES et al., 2016), giving rise to the presence of numerous larger diameter trees and characterizing an asymmetrical distribution skewed to the right. On the other hand, high numbers of recruits and younger individuals have been observed in disturbed areas such as scrubland, open forests with bamboo and forests that have been subjected to intensive extraction, resulting in an asymmetrical distribution skewed to the left (WADT et al., 2005; SCOLES; GRIBEL, 2011).

Studies focusing on the relationship between diameter structure and fruit production have revealed that intermediate-diameter trees are more densely distributed and produce more fruit. Moreover, it would appear that total production is concentrated in a small number of individuals, such that few trees are highly productive while many trees produce little (ZUIDEMA, 2003; KAINER et al., 2007; GUEDES et al., 2014; TONINI; PEDROZO, 2014). Productivity can be highly variable with individual specimens bearing between 0 and 1340 fruits per tree (TONINI; PEDROZO, 2014) and with population means ranging from 21 to 184 fruits and 3.4 to $24 \mathrm{~kg}$ per tree (ZUIDEMA, 2003; WADT et al., 2005; KAINER et al., 2007, TONINI; PEDROZO, 2014). Variations in yield from one harvest to another are also very high, and in some regions a tree may produce 8 to 52 times more seeds in high-yielding years than in low-yielding years, making market prognosis difficult and profitability uncertain (TONINI; PEDROZO, 2014).

Furthermore, there is a strong correlation between reproductive status and tree size (ZUIDEMA; BOOT, 2002; WADT et al., 2005; KAINER et al., 2007; STAUDHAMMER et al., 2013; NEVES et al., 2016). Light incidence and crown position are directly associated with the diameter at breast height (DBH: $1.3 \mathrm{~m}$ above ground level), since trees reach the canopy when they attain a DBH between 20 and $30 \mathrm{~cm}$, at which point they become emergent and begin to expand their crown. When trees reach DBH values between 40 and $60 \mathrm{~cm}$ they become regular fruit producers (ZUIDEMA, 2003). These relationships have been shown to be valid for a large region of the Amazon (ZUIDEMA; BOOT, 2002; WADT et al., 2005; TONINI; PEDROZO, 2014; GUEDES et al., 2014; NEVES et al.,2016), and on this basis it is possible to determine the minimal reproductive size for different populations of B. excelsa. This discovery represents a major advance in the process of estimating the potential production of native Brazil nut trees (NEVES et al., 2016).

Mean DBH values of Brazil nut trees groves in Brazil and Bolivia reportedly vary between 32.5 and 38.5 $\mathrm{cm}$ (WADT et al., 2005; GUEDES et al., 2014), confirming the threshold of $40 \mathrm{~cm}$ proposed by Zuidema (2003) for the classification of individuals as young or adult in different populations. However, following the analysis of a Brazil nut population in Xapuri (Acre, Brazil), Wadt et al. (2005) proposed a DBH of $50 \mathrm{~cm}$ as the borderline for categorizing populations according to reproductive maturity and adopted an ontogenetic criterion for the classification of forests in Acre. This classification has been used as a standard for studies on the population 
dynamics of $B$. excelsa in diverse forest types and areas of the Amazon Basin (NEVES et al., 2016). However, a generalization of this nature may not be valid for the whole of the Brazilian Amazon given the small number of publications that have focused on the association between diameter structure and fruit production in native Brazil nut trees, the vast size of the region, the variability of forest typologies, and the degree of intensity of natural and anthropogenic disturbances to which the forests may have been subjected.

In the light of the above mentioned, the objectives of this study were (i) to evaluate the annual variation in fruit and seed production and productivity of Brazil nut trees at the individual and populational level; (ii) to determine the association between diameter structure and fruit/seed production in a semi-deciduous seasonal forest undergoing logging in Mato Grosso, Brazil.

\section{MATERIALS AND METHODS}

\section{Study site}

The study was conducted in the municipality of Itaúba (Mato Grosso, Brazil) in a semi-deciduous submontane seasonal forest with emergent canopy (IBGE, 2012). According to the Köppen climate classification, the region is characterized by a tropical humid or sub-humid climate type Am with an average annual precipitation of around $2000 \mathrm{~mm}$ and a well-defined dry period of two to three months (ALVARES et al., 2013). The study area encompassed a 2000 ha region of forest located inside the rural property Fazenda Santo Angelo (11 ${ }^{\circ} 5.561^{\prime} 41^{\prime \prime S}$, $55^{\circ} 21.2^{\prime} 42^{\prime \prime} \mathrm{W}$ ) belonging to the Dalpai Group. The area has been exploited since 1998 under a sustainable forest management plan for logging purposes with a cutting cycle of 25 years, and is currently under constant and annual collection of Brazil nuts. Extractivism is practiced under a lease arrangement in which fruits are collected once or twice during the period of fruit drop and the harvesters pay a percentage (from 10 to $15 \%$ ) of the production to the landowner.

\section{Data collection}

Data were collected at two permanent plots (PP), each of 9 ha (300 m x $300 \mathrm{~m})$, that had been selected on the basis of ease of access and density of Brazil nut trees. The PPs were set up in 2011 (PP1) and 2013 (PP2) at a straight line distance apart of $3.5 \mathrm{~km}$, and all trees with $\mathrm{DBH} \geq 10 \mathrm{~cm}$ in each plot were numbered and marked with aluminum tags. The production of fruits and seeds was monitored annually in the middle and at the end of the rainy season, corresponding to the period of fruit drop that lasts from October to February. A total of 279 trees in the two PPs were monitored during the five harvesting seasons between 2012 and 2017.

The parameters $\mathrm{DBH}$, crown position, crown shape and fruit production were employed as indicators of the tree maturity. DBH was determined using a measuring tape, while the crown position (dominant, co-dominant, dominated and suppressed) and crown shape (complete, incomplete but more than half intact, incomplete with less than half intact, and poor) were assessed qualitatively as described by Wadt et al. (2005).

All of the fruits from each study tree were counted and $30 \%$ of them were opened in order to count and weigh the seeds with the purpose of establishing the mean fresh weight of seeds per tree (SFW tree ${ }^{-1}$ ) according to the method described by Tonini (2013). One composed samples of seeds (1 kg) obtained from each PP were transferred to the laboratory and dried to constant weight in a fan-assisted oven at $60^{\circ} \mathrm{C}$, in order to determine mean water content. The mean seed dry weight per tree (SDW tree ${ }^{-1}$ ) was calculated from the mean SFW tree $e^{-1}$ and the mean water content, and subsequently multiplied by the total number of fruits per tree to estimate the total SDW tree ${ }^{-1}$. Trees were categorized into five classes according to their seed production, namely: no productivity, low productivity (above zero and up to the 40th percentile), intermediate productivity (between the 40th and 60th percentiles), high productivity (between the 60th and 90th percentiles), and very high productivity (above the 90th percentile).

\section{Statistical analysis}

The Kolmogorov-Smirnov test was used to compare the frequency distributions by diameter class of trees in PP1 and PP2 adjusted by the Weibull distribution, and Student's $t$ test was applied to compare seed production between the two plots and the five harvesting seasons with the level of significance set at $p \leq 0.05$ for both tests. The annual variation in production was estimated using the coefficient of variation (CV) as described by Kelly and Sork (2002). Variability of the population regarding the number of fruits was determined as the mean 
coefficient of variation $\left(\mathrm{CV}_{\mathrm{p}}\right)$ resulting from the variability per year per plot, while individual variability was obtained by calculating the mean coefficient of variation $\left(\mathrm{CV}_{\mathrm{i}}\right)$ of the number of fruits produced per tree in each year. Since determination of the dry weight of seeds involves time-consuming field and laboratory procedures, we constructed a model based on the number of fruits (NF) to facilitate the estimation of seed production and to prevent possible errors. A model of this nature is justified because the sizes and weights of seeds differ from tree to tree, and this may generate inaccuracies in estimating production since seed production is not necessarily a linear function of NF.

Stepwise regression analysis was used to verify the relationship between trunk dimensions, crown position and crown shape with seed production (SDW tree $\left.{ }^{-1}\right)$. As independent variable, DBH and basal area $\left(\mathrm{m}^{2}\right)$ were tested in linear, quadratic, cubic, logarithmic and inverse regressions for $95 \%$ reliability. Subsequently, the qualitative variables (crown position and crown shape) were included in the model with the application of a dummy variable (D). For this purpose, two groups of interest were defined, namely dominant and co-dominant trees with complete crowns $(\mathrm{D}=0)$ and dominant and co-dominant trees with incomplete crowns $(\mathrm{D}=1)$. These two groups were defined because dominated and suppressed trees do not produce fruits (ZUIDEMA, 2003) and the presence of lianas was considered indirectly since that is correlated to crown rupture and malformation (Wadt et al., 2005).

The assumptions of regression analysis (i.e. normality, homoscedasticity of variance and independence of residuals) were verified using Saphiro-Wilk, Levene and Durbin-Watson tests, respectively, with quantitative variables transformed as necessary. The significance and goodness of fit of the models was substantiated using analysis of variance (ANOVA), the coefficient of determination $\left(\mathrm{R}^{2}\right)$ obtained according to Kvàlsethto allow comparison between models with and without intercept, standard error of estimate (Syx) and analysis of residues.

\section{RESULTS}

A total of 279 Brazil nut trees were monitored in plots PP1 and PP2 during the five harvesting seasons between 2012 and 2017, and some 10,699 fruits were counted, of which $61.8 \%$ were dispersed in the months of October to December in the respective years. The mean water content of the seeds was determined to be $46.2 \pm$ $14.4 \%$, giving an estimated total SDW over the monitoring period of $4214.45 \mathrm{~kg}$. Productivity did not differ statistically between the sampling plots during the harvesting seasons 2014/2015, 2015/2016 and 2016/2017 [T $(5 \%, 4)=0.39, p=0.36]$ with mean values in five harvesting seasons of $595 \pm 365$ fruits ha ${ }^{-1}$ and $58.5 \pm 40.1 \mathrm{~kg}$ $\mathrm{ha}^{-1}$ for seeds. The highest seed productivity was observed in the 2014/2015 harvesting season $\left(106.1 \mathrm{~kg} \mathrm{ha}^{-1}\right)$ while the lowest was recorded in 2016/2017 (11.2 $\mathrm{kg} \mathrm{ha}^{-1}$ ), corresponding to a difference of $94.9 \mathrm{~kg} \mathrm{ha}^{-1}$ (Figure $1 \mathrm{~A})$.

The annual variation between populations with regard to fruit productivity was higher than the individual variability, as shown by the values of $\mathrm{CV}_{\mathrm{p}}$ and $\mathrm{CV}_{\mathrm{i}}$ (1.82 and 1.02, respectively). The adherence test indicated that there were no statistical differences between PP1 and PP2 regarding the frequency distributions by diameter class $\left(\mathrm{D}=0.1841\right.$ and $\left.\mathrm{D}_{\text {critical }}=0.409\right)$, hence data from the two plots were pooled for subsequent analysis. As shown in Figure 1B, the diameter distribution was continuous, unimodal, with a clear peak in the center of the $15 \mathrm{~cm}$ class, and with the greater number of individuals in the smaller diameter classes. The density of $B$. excelsa was 15 trees $\mathrm{ha}^{-1}$ and the mean and median DBH values were 59.9 and $63.05 \mathrm{~cm}$, respectively. 


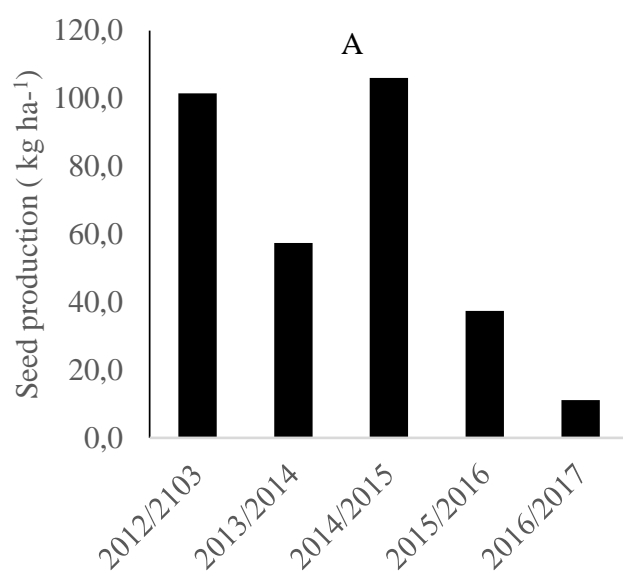

Harvesting seasons

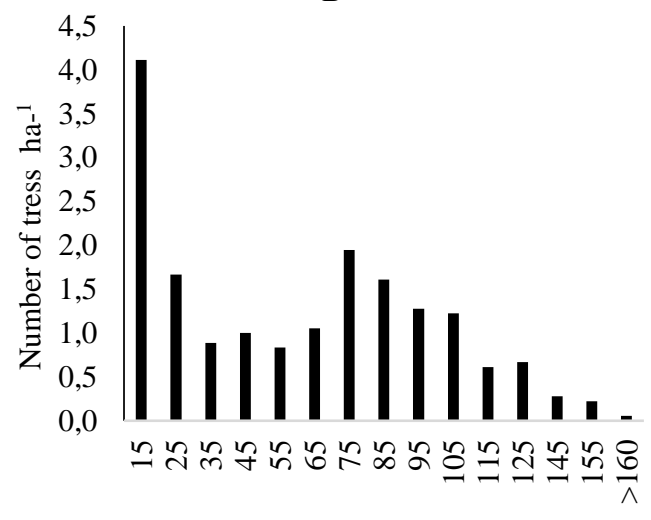

Diameter classes

Figure 1. Seed production per harvesting season (A) and diameter distribution (B) in native Brazil nut stands located in Itaúba, MT, Brazil.

Figura 1. Produção de sementes por safra (A)distribuição diamétrica (B) em um castanhal nativo localizado em Itaúba, MT, Brasil.

Trees with $10 \mathrm{~cm} \leq \mathrm{DBH}<30 \mathrm{~cm}$ were characterized by the predominance of dominated or suppressed individuals (60\% of the total) with malformed crowns (53.1\% of the total). Moreover, only $3.5 \%$ of these trees produced seeds (Figure 2) and individual yields were very low with a mean value of $0.12 \mathrm{~kg}^{2}$ tree $^{-1}$ year $^{-1}$ representing just $0.3 \%$ of the total production. Some $96 \%$ of trees with $30 \mathrm{~cm} \leq \mathrm{DBH}<70 \mathrm{~cm}$ reached the upper layers of the canopy and 55.3\% of such individuals presented well-formed crowns. Moreover, the majority of trees (63\%) within this DBH range started to produce seeds with an average of $1.23 \mathrm{~kg}^{\text {tree }} \mathrm{year}^{-1}$, accounting for $9 \%$ of the total seed production. All trees with DBH values $\geq 70 \mathrm{~cm}$ reached the upper canopy and the majority became dominant with good crown formation. The mean seed production of this group was $4.8 \pm 6.1 \mathrm{~kg}^{\mathrm{g}} \mathrm{tre}^{-1} \mathrm{year}^{-1}$ and these trees accounted for $90.4 \%$ of the total seeds produced. The highest yields of seeds were recorded in trees with $\mathrm{DBH} \geq 160 \mathrm{~cm}$, a single individual of which produced $69.9 \mathrm{~kg} \mathrm{tree}^{-1}$ year $^{-1}$ and $1.7 \%$ of the total seed production.

As shown in Table 1, seed productivity was zero or low for a large proportion $(46.2 \%)$ of the trees. In contrast, $39.0 \%$ of the trees exhibited high or very high productivity that accounted for $92.9 \%$ of the total fruit produced per year and $93.5 \%$ of the annual SDW. A group of 23 trees ( $8.2 \%$ of the total number) with mean DBH of $111 \mathrm{~cm}$ exhibited the highest productivities and together produced 1.86-times more fruit and 1.77-times more seed than all of the other 256 trees of the study population. 


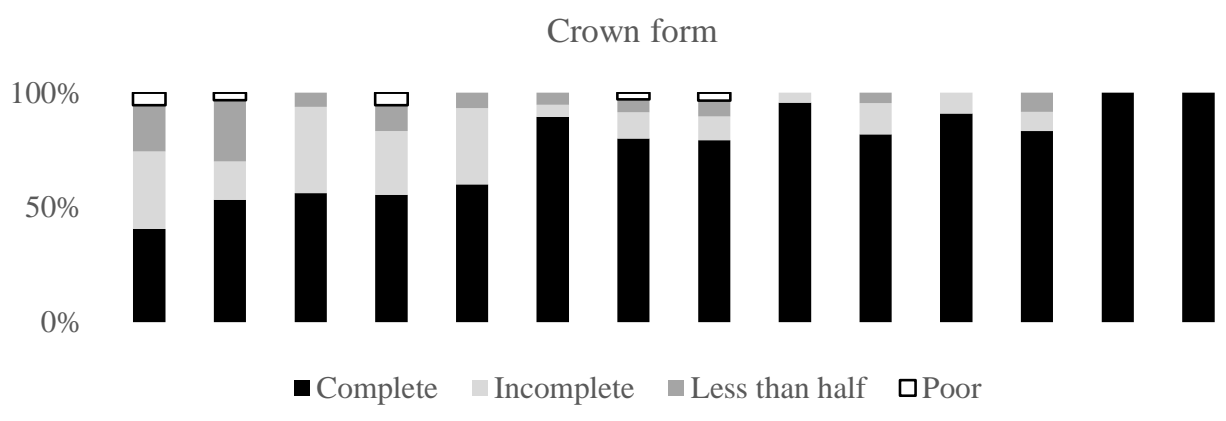

B

Crown position

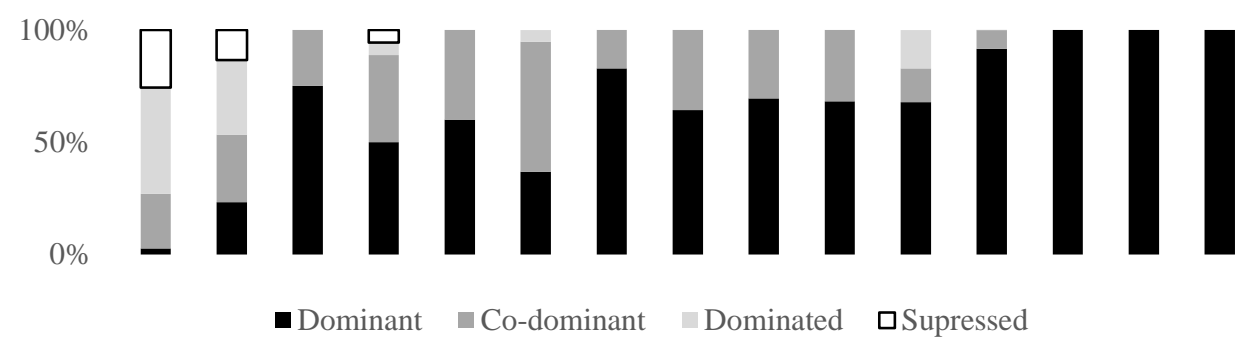

A

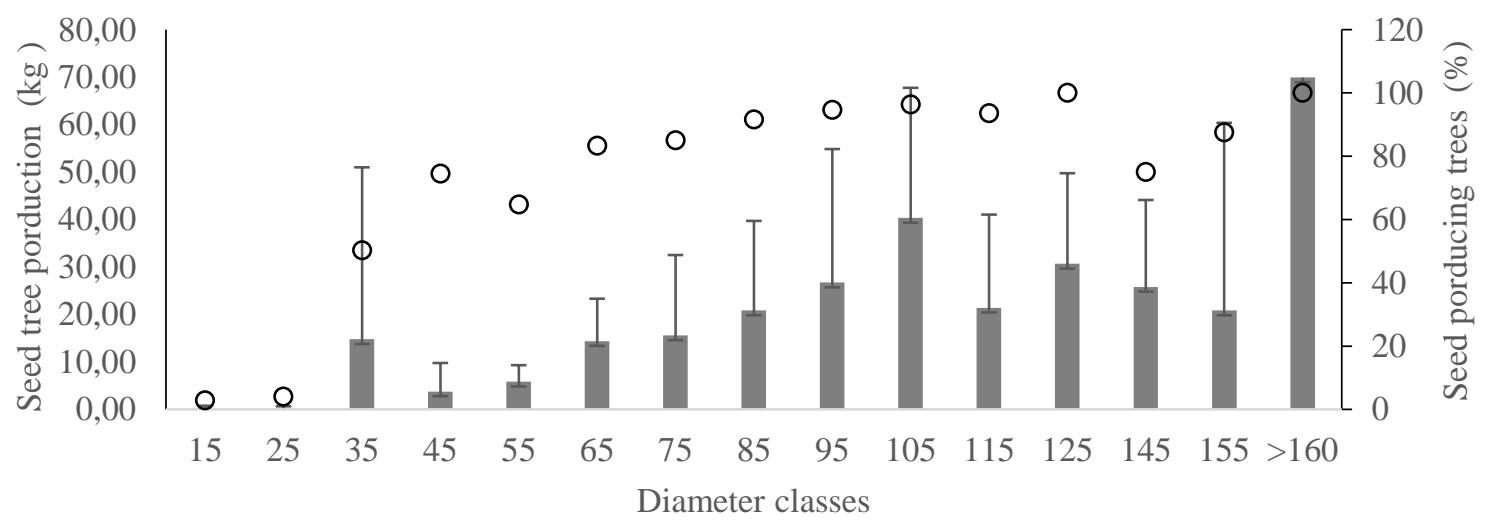

Figure 2. Mean seed productivity of native Brazil nut stands located in Itaúba, MT, Brazil, distributed according to diameter class (A) crown position (B) and crown shape (C).

Figura 2. Produção média de sementes de castanheiras-do-brasil localizadas em Itaúba, MT, Brasil, distribuídas por classe diamétrica(A), posição da copa (B) e forma da copa (C). 
Table 1. Classification of native Brazil nut trees located in Itaúba, MT, Brazil, according to fruit and seed productivity.

Tabela 1.Classificação das castanheiras-do-brasil localizadas em Itaúba, MT, Brasil, de acordo com a produtividade de frutos e sementes.

\begin{tabular}{|c|c|c|c|c|c|c|c|c|}
\hline \multirow{2}{*}{$\begin{array}{l}\text { Production } \\
\text { class }\end{array}$} & \multirow{2}{*}{$\begin{array}{c}\text { Mean DBH } \\
(\mathrm{cm})\end{array}$} & \multicolumn{2}{|c|}{ Trees } & \multicolumn{2}{|c|}{ Fruit production } & \multicolumn{2}{|c|}{ Seed production } & \multirow{2}{*}{$\begin{array}{l}\text { Seed production } \\
\left(\mathrm{kg} \mathrm{fruit}^{-1}\right)\end{array}$} \\
\hline & & $n$ & $\%$ & $\left(\right.$ fruits tree ${ }^{-1}$ year $\left.^{-1}\right)$ & $\%$ & $\left(\mathrm{~kg}\right.$ tree $\left.^{-1} \mathrm{year}^{-1}\right)$ & $\%$ & \\
\hline Zero & $19.3 \pm 11.7$ & 97 & 34.7 & 0 & 0 & 0 & 0 & 0 \\
\hline Low & $56.5 \pm 28.3$ & 32 & 11.5 & $3.0 \pm 2.5$ & 0.89 & $0.31 \pm 0.23$ & 0.8 & 0.103 \\
\hline Intermediate & $63.1 \pm 21.3$ & 41 & 14.7 & $16.0 \pm 8.0$ & 6.13 & $1.72 \pm 0.76$ & 5.6 & 0.107 \\
\hline High & $89.9 \pm 22.5$ & 86 & 30.8 & $71 \pm 46.0$ & 57.0 & $7.06 \pm 4.1$ & 53.8 & 0.099 \\
\hline Very high & $111.0 \pm 21.6$ & 23 & 8.2 & $167 \pm 53.0$ & 35.9 & $16.1 \pm 4.06$ & 39.7 & 0.096 \\
\hline
\end{tabular}

Since trees with $10 \mathrm{~cm} \leq \mathrm{DBH}<30 \mathrm{~cm}$ were considered immature from a reproductive point of view, 96 trees were excluded from models that aimed to explain the relationship between the predictor (DBH, crown position and crown shape) and response (SDW) variables. Following square root transformation of the dependent variable (mean SDW tree ${ }^{-1}$ ), the assumptions of regression analysis were satisfied (Levene's test $(2,160)=2.02, p$ $=0.094$; Saphiro-Wilk test, $\mathrm{W}(165)=0.975$; Durbin-Watson test $=2.039, p=0.05)$. ANOVA indicated that there were significant associations between SDW with DBH and crown variables (Table 2). No significance was observed for the intercept in the initial fitting of data with models, hence further fitting was performed without the intercept.

Table 2. Stepwise regression analysis of the models developed to explain associations between seed production (SDW tree ${ }^{-1}$ ) and the variables $\mathrm{DBH}$, crown position and crown shape.

Tabela 2.Análise de regressão passo-a-passo dos modelos criados para estabelecer as associações entre a produção de sementes (SDW árvore ${ }^{-1}$ ) e as variáveis DBH, posição e forma da copa.

\begin{tabular}{|c|c|c|c|c|c|c|c|c|c|c|}
\hline \multirow[b]{2}{*}{ Models } & \multicolumn{6}{|c|}{ Coefficients } & \multicolumn{4}{|c|}{ Goodnessoffit } \\
\hline & $\beta_{1}$ & $t$ test & $p$ & $\beta_{2}$ & $\begin{array}{c}t \\
\text { test }\end{array}$ & $p$ & $\mathrm{R}^{2}$ & Syx & $\mathrm{F}$ & $p$ \\
\hline $\mathrm{SDW}=\left(\beta_{1} \mathrm{DBH}\right)^{2}$ & 0.0254 & 29.7 & $>0.001$ & - & - & & 0.34 & 0.989 & 899.8 & $<0.001$ \\
\hline $\mathrm{SDW}=\left(\beta_{1} \mathrm{DBH}+\beta_{2} \mathbf{D}\right)^{2}$ & 0.0261 & 29.1 & $>0.001$ & -0.469 & 2.16 & 0.003 & 0.35 & 0.988 & 438.5 & $<0.001$ \\
\hline $\mathrm{SDW}=\beta_{1} \mathbf{N F}+\beta_{2} \mathbf{N F}^{2}$ & 0.114 & 41.0 & $>0.001$ & -0.0001 & 7.6 & $>0.001$ & 0.97 & 1.256 & 3779.7 & $<0.001$ \\
\hline
\end{tabular}

$\overline{\mathrm{SDW}}$, mean seed dry weight per tree; DBH, diameter at breast height; $\mathrm{D}$, dummy variable; NF, mean number of fruits per tree; $\mathrm{R}^{2}$, coefficient of determination; Syx, standard error of estimate; F = Fisher-Snedcor distribution.

The first model, which contained only the variable DBH, explained $34 \%$ of the variability in seed production, whereas the inclusion of the dummy variable D (relating to crown position and crown shape) in the second model increased the goodness of fit although the gain was small $(1 \%)$. The negative value of the coefficient $\beta_{2}$ associated with $\mathrm{D}$ indicates that seed productivity was significantly reduced in trees with damaged crowns. The third model showed that the variable NF was a good predictor of SDW with the relationship being better explained by a quadratic equation without intercept. Based on the first model, it is estimated that seed production would increase by an average of $1.3 \mathrm{~kg}$ for every $10 \mathrm{~cm}$ increase in DBH. Observed values of seed production and those obtained through application of the first and third models are plotted in Figure 3. 


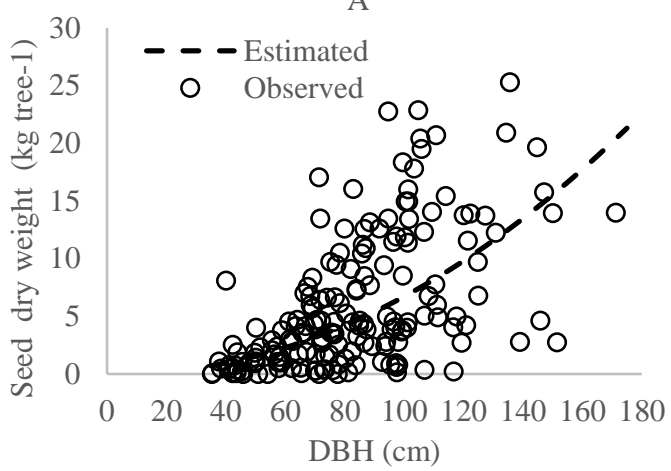

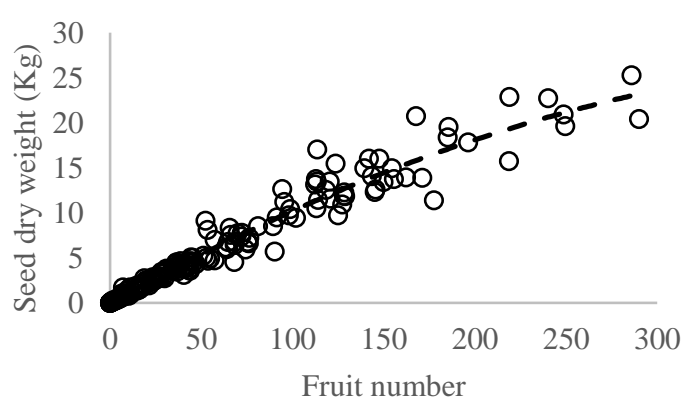

Figure 3. Regression plots representing seed dry weight $v s$. diameter at breast height (A) and seed dry weight $v s$. number of fruits $(\mathrm{B})$.

Figura 3. Curvas de regressão representando peso seco de sementes vs. diâmetro à altura do peito (A) e peso seco de sementes $v s$. número de frutos (B).

\section{DISCUSSION}

Evaluations performed in Itaúba (MT) over five harvesting seasons revealed that the annual variation between populations with regard to fruit productivity was higher than the individual variability, corroborating the results reported by Tonini and Pedrozo (2014) for Brazil nut groves in the State of Roraima.

Most of the variability reported in the present study can be attributed to the drastic drop in production that occurred in the 2016/2017 harvest (Figure 1A). This phenomenon was perceived throughout the Amazon Basin and gave rise to a reduction of $70 \%$ in overall yield compared with those recorded in previous years (EMBRAPA, 2018). Such reduction in productivity may be explained by an unidentified climatic effect, most likely diminution of rainfall brought about by natural phenomena such as "El Niño" (ZUIDEMA; BOOT, 2002; ZUIDEMA, 2003).

The pattern of fruit dispersal observed in Itaúba was similar to that reported in northern Bolivia and Chico Mendes Agroextractive Settlement Project (PAE Chico Mendes, Acre, Brazil) (ZUIDEMA; BOOT, 2002; WADT et al., 2018), where fruit drop occurred from November to February with a peak fall in November and December, coinciding with the beginning of the rainy season. Our results apparently disagree with those of Wadt et al. (2018), who described that fruit drop was concentrated at the start of the rainy season and that $94 \%$ of fruits were dispersed in the first 50 days. However, it is important to draw attention to the fact that our result represents the mean fall rate, although the annual variations were wide (36.7 to $87.1 \%$ ) so that in some years the fall rate was very close to that reported by Wadt et al. (2018).

In Itaúba, a large number of the trees were categorized within the smaller diameter classes, a pattern that appears to be typical of open forests (WADT et al., 2005) such as those occurring in Acre. This result supports previous findings (THOMAS et al., 2015) that the forests of western Amazon are more susceptible to natural disturbance and the formation of natural clearings that benefit the spontaneous regeneration of the species. In the light of previous studies (MOLL-ROCEK et al., 2014; SCHÖNGART et al., 2015), it can be hypothesized that forest gaps resulting from logging activities and the associated vegetation physiognomy have had a strong impact on natural regeneration in the studied area leading to an abundance of individuals in the small diameter classes. In this context, Moll-Rocek et al. (2014) found a significantly higher recruit density in logging gaps in the Peruvian Amazon together with a positive correlation between recruit density and canopy openness, and increased growth rates in tree-fall gaps, thereby confirming B. excelsa as a gap-dependent species. Furthermore, Schöngart et al. (2015) compared age-diameter relationships, mean passage time through $10 \mathrm{~cm}$ diameter size classes, and growth trajectories of individual Brazil nut trees and concluded that the average time to attain a DBH of $10 \mathrm{~cm}$ was $27 \pm$ 10.1 years. This finding is compatible with the results of our study since logging activities have been ongoing at the Itaúba site for some 20 years.

According to the classification proposed by Wadt et al. (2005), $82.7 \%$ of trees in the study population would be considered young (i.e. $\mathrm{DBH} \leq 100 \mathrm{~cm}$ ), indicating that long-term production of Brazil nuts could be sustained in Itaúba. In addition, the percentage of young trees was higher in comparison with the six groves located in the States of Acre and Amapá (30-68.7\%) investigated earlier by Neves et al. (2016).

In more open areas with better light conditions, trees are expected to reach the reproductive stage when they are smaller (ZUIDEMA, 2003; GUEDES et al., 2014). In Itaúba, we observed that some trees with DBH values between 10 and $20 \mathrm{~cm}$ produced fruits even though their dimensions were below the minimal reproductive 
diameter of 32.4 - $40.9 \mathrm{~cm}$ reported earlier for Bolivian and Brazilian forests with no recent history of logging (ZUIDEMA, 2003; WADT et al., 2005; GUEDES et al., 2014; NEVES et al., 2016). The high percentage of small Brazil nut trees in our study area with crowns occupying upper canopy positions also reinforces the hypothesis that light conditions in our research plots are better than in other forest stands without a recent history of logging. Furthermore, $26 \%$ of the trees classified within the DBH range $10-30 \mathrm{~cm}$ were considered dominant and this proportion was much higher than that observed in an open forest with bamboo located in Xapuri (Acre) in which $10 \%$ of individuals in this dimension range were dominant but produced no fruits (STAUDHAMMER et al., 2013).

Based on crown variables (shape and light conditions), seed production and the percentage of fruitproducing trees, it is possible to classify individual Brazil nut trees into three developmental phases, namely: (i) juvenile $(10 \mathrm{~cm} \leq \mathrm{DBH}<30 \mathrm{~cm})$ with a predominance of dominated trees, of which only a small percentage produced fruits; (ii) intermediate or pre-adult $(30 \mathrm{~cm} \leq \mathrm{DBH}<70 \mathrm{~cm})$ with a predominance of individuals in upper canopy positions and exhibiting good crown shape, but still with a large proportion $(44.7 \%)$ of non-producing individuals; and (iii) adult ( $\geq 70 \mathrm{~cm}$ DBH) with all individuals in upper canopy positions and exhibiting wellformed crowns producing $90.4 \%$ of the total seed production. According to this classification, only $1.4 \%$ of the trees in the Itaúba population were unproductive.

Interestingly, trees in our study plots were able to attain the intermediate or pre-adult phase with DBH values smaller than the $50 \mathrm{~cm}$ cut-off point suggested by Wadt et al. (2005) as the border between juveniles and adults in forests in Acre. Our results, taken together with the report by Guedes et al. (2014) that Brazil nut trees in Amapá presenting DBH values $>73.6 \mathrm{~cm}$ produced higher yields, indicate that the ontogenetic-based classification proposed by Wadt et al. (2005) for forests in Acre should be used with discretion and may not be appropriate for all forest physiognomies and levels of anthropogenic disturbance encountered in the Amazon Basin.

The characterization of potentially productive trees is relevant for predicting the future production of Brazil nut groves as well as comparing yields at different sites. Even though $74 \%$ of trees with DBH $\geq 40 \mathrm{~cm}$ produced fruits in Itaúba, the proportion $(61.7 \%)$ of these potentially productive trees was significantly smaller than the values reported earlier for the Dense Ombrophylous Forest of Oriximiná, State of Pará (92.5\%; SCOLES; GRIBEL, 2012) and the forests undergoing intense timber exploitation in Tambopata, south-western Peru (between 77.4 and $88.5 \%$; ROCKWELL et al., 2017).

In Itaúba, mean yields of $38.1 \pm 57.8$ fruits tree $^{-1}$ year $^{-1}$ and $3.81 \pm 5.4 \mathrm{~kg}$ seeds tree $\mathrm{year}^{-1}$ were recorded when all monitored trees $(\mathrm{DBH} \geq 10 \mathrm{~cm})$ were taken into account, but when only potentially productive $(\mathrm{DBH} \geq$ $40 \mathrm{~cm})$ or adult $(\mathrm{DBH} \geq 70 \mathrm{~cm})$ trees were considered, the mean values increased, respectively, to $61.1 \pm 62.8$ and $77.7 \pm 67.3$ fruits tree ${ }^{-1}$ year $^{-1}$ and $4.09 \pm 5.8$ or $7.6 \pm 6.2 \mathrm{~kg} \mathrm{seeds}$ tre $^{-1}$ year $^{-1}$. Comparing these data with studies of a similar nature, it is possible to infer that tree sampling and the time of monitoring may conceal the true differences in site-related factors or the genetic potential of different individuals and/or populations. Although the mean yields described here appear to be lower than those reported previously for sites in the Bolivian Amazon (ZUIDEMA; BOOT, 2002) and the Reserva Extrativista do Rio Cajari, Amapá (NEVES et al., 2015), with means ranging between 102 to 184 fruits tree ${ }^{-1}$ during one to four years of monitoring, such comparisons are unsound since the former study limited tree sampling to individuals with DBH $>60 \mathrm{~cm}$ while the latter considered all fruitproducing trees as having $\mathrm{DBH} \geq 10 \mathrm{~cm}$. The present study suggests that the Brazil nut trees in Itaúba exhibit intermediate production with yields within the range observed in sites in other Amazonian States. For instance, in Acre the yields were 18 to 66.2 fruits tree ${ }^{-1}$ and 10.28 to $24 \mathrm{~kg}$ seeds tree ${ }^{-1}$ year $^{-1}$ (WADT et al., 2005; KAINER et al., 2007), whereas in three groves in Roraima the mean yields were 27 to 121 fruits tree ${ }^{-1}$ year $^{-1}$ and 4.2 to 13.9 $\mathrm{kg}$ seeds tree ${ }^{-1}$ year $^{-1}$ (TONINI; PEDROZO, 2014). However, in the latter studies the researchers took into account only trees with $\mathrm{DBH} \geq 50 \mathrm{~cm}$ and monitored productivity over four to seven years.

However the productivity observed in Itaúba can be considered high ( 595 fruits and $58.54 \mathrm{~kg}$ of seeds ha$\left.{ }^{1}\right)$ owing to the numerous productive trees $\left(30\right.$ trees $\left.\mathrm{ha}^{-1}\right)$. Other reports have described a variable number of productive trees $\left(0.91\right.$ to 13.2 trees ha $^{-1}$ ), the productivity of which ranged between 72 and 762 fruits (ZUIDEMA; BOOT, 2002), KAINER et al., 2007; WADT et al., 2008; TONINI; PEDROSO, 2014). Our study is the first to report the production of Brazil nuts in terms of SDW $(\mathrm{kg})$, so that it is not possible to compare this variable with other studies.

DBH is the most significant variable for calculating productivity of native Brazil nuts (ZUIDEMA, 2003; WADT et al., 2005; KAINER et al., 2007) and accounted for 34\% of the annual variation in the mean SDW, a finding similar to that reported by Wadt et al. (2005). In a study by Kainer et al. (2007), in which the monitoring period was much longer, DBH reportedly accounted for $56.6 \%$ of the annual variation in fruit production. In the present study, inclusion of qualitative crown variables in the model did not influence the predictions as expected, probably because of the low percentage (12.5\%) of dominant and co-dominant individuals with broken crowns observed in the sample population. 
Theoretically, the precision of the models can be increased by including quantitative crown data such as diameter and area, but the gain in precision does not always compensate for the extra effort and costs involved in data collection. Zuidema (2000) stated that crown area is a much better predictor of fruit production than DBH and such assertion has been corroborated by Neves et al. (2015), who reported a significant predictive gain for fruit production (18.5\% of the variance explained by regression) when DBH was replaced by crown area. However, Kainer et al. (2007) observed that the predictive differences between DBH and crown area were very small, although DBH facilitates data collection because it is a common field measurement. Crown position or ability to access light resources are clearly important determinants of fruit production, but since almost all B. excelsa adult and productive trees had a co-dominant or dominant canopy position, this variable fell out of Kainer's model. Climatic variables such as rainfall during the transition period between the dry and rainy season (IVANOV et al. 2018) and soil attributes such as cation exchange capacity have been used as potential production predictors in native Brazil nut orchards (KAINER et al., 2007), although they require verification via more comprehensive studies.

The DBH model established here predicted that seed productivity would increase by $1.3 \mathrm{~kg}$ for every 10 $\mathrm{cm}$ diameter without the population showing clear signs of senescence. Absence of senescence is not normally observed in closed forests since the relationship between productivity and DBH tends to be non-linear with the most productive trees being those with intermediate diameter rather than the broader ones (WADT et al., 2005; KAINER et al., 2007; GUEDES et al., 2014; NEVES et al., 2015). It is likely that the pattern reported here was occasioned by improved light conditions in the studied plots together with the younger population, although this hypothesis must be tested by dendrochronological investigation.

The data produced in this study confirmed the general pattern observed in Brazilian and Bolivian stands of B. excelsa in which production of Brazil nuts is concentrated in a small number of trees (ZUIDEMA, 2003, KAINER et al., 2007; TONINI; PEDROZO, 2014). In the present case, for example, $8.2 \%$ of the individuals accounted for $39.7 \%$ of seed productivity. Identification, propagation and planting such individuals in natural clearings or openings created by logging together with the application of silvicultural techniques, such as pruning that increase radial growth rate, would appear to be appropriate approaches to increase productivity in native Brazil nut stands.

\section{CONCLUSIONS}

- The production pattern for native B. excelsa stands observed in this study is in line with that observed in other parts of the Amazon Basin and is characterized by large inter-annual variations and seed productivity relying on a small number of individuals. Brazil nut production in the study area (61 fruits tree $^{-1}$ year $^{-1}$ and $4.09 \mathrm{~kg}$ seeds tree ${ }^{-1}$ year-1) was considered intermediate when compared with yields recorded in similar studies. However, owing to the high number of productive trees, the productivity was rather high, i.e. 595 fruits and $58.54 \mathrm{~kg}$ of seeds ha-1.

- There was a significant association between seed productivity and DBH together with qualitative crown variables that explained 35\% of the variation in SDW. The model developed with SDW as a function of NF showed good precision.

- The smallest diameter classes comprised the largest number of individuals and the minimal reproductive diameter was below that commonly observed in other areas of the Amazon. The trees reached the intermediate or pre-adult phase with a DBH smaller than $50 \mathrm{~cm}$, a value that has been proposed as borderline between juveniles and adults in studies involving population dynamics of $\mathrm{B}$. excelsa. This discrepancy may be explained by the improved light conditions resulting from the floristic environment and clearings produced by logging activities.

\section{ACKNOWLEDGMENTS}

This research was supported by Conselho Nacional de Desenvolvimento Científico e Tecnológico (CNPqProcesso 472988/2013-1).

\section{REFERENCES}

ALVARES C.A.; STAPE, J.L.; SENTELHAS, P.C.; GONÇALVES,L.L.M.; SPAROVEC, G. Köpen's climate classification map for Brazil. Meteorologische Zeitschrift, Stutgard, v.22, n.6, p. 711-728, 2013.

INSTITUTO BRASILEIRO DE GEOGRAFIA E ESTATÍSTICA. Manual técnico da vegetação brasileira. Rio de Janeiro:IBGE, 2012, $271 \mathrm{p}$. 
IVANOV, G.B.; FLEIG, F.D.; TONINI, H. Fatores edafoclimáticos relacionados a produção de sementes em castanhais nativos de Roraima. Pesquisa Florestal Brasileira, Curitiba v.38,p:1-6,2018.

KAINER, K. A.; WADT, L. H. O.; STAUDHAMMER, C. L. Explaining variation in Brazil nut fruit production. Forest Ecology and Management, Amsterdam, v. 250, p. 244-255, 2007.

KELLY, D.; SORK, V. Mast seedling perennial plants: why, how, where? Annual Review of Ecological Systems, v.33, p.427-447, 2002.

NEVES, E.S.; GUEDES, M.C.; RODRIGUES, E.G. Relação da produção de frutos de castanha-da-amazônia (Bertholethia excelsa Bonpl.) com variáveis das próprias castanheiras em capoeira e floresta da Resex Cajari. Biota Amazônica, Macapá, v.5, n.2, p.31-37, 2015.

NEVES, E.S.N.; WADT, L.H.O.; GUEDES, M.C. Estrutura populacional e potencial para o manejo de Bertholletia Excelsa (Bonpl.) em castanhais nativos do Acre e Amapá. Scientia Forestalis, Piracicaba, v.44, n.109,p.19-31, 2016.

GUEDES, M.C.; NEVES,E.S.; RODRIQUES, E.G. Castanha na roça: Expansão da produção e renovação dos castanhais em áreas de agricultura itinerante no Amapá, Brasil.Boletim do Museu Paraense Emilio Goeldi, Belém, v.9, n.2, p.381-398, 2014.

ROCKWELL, C.A.; GUARIGUATA, M.R.; MENTON, M.; QUISPE, E.A.; QUAEDVILIEG, J.; WARRENTHOMAS, E.; SILVA, H.F.; ROJAS, E.E.J.; ARRUNÁTEGUI, J.A.H.K.; VEGA, L.A.M.; HANCCO, R.Q.; VERA, O.R.; TITO, J.F.V.; PANDURO, B.T.V.; SALAS, J.J.Y. Spatial distribution of Bertholletia excelsa in selectively logged forests of the peruvian Amazon. Journal of Tropical Ecology, Cambridge, v.33, p.114-127, 2017.

MOLL-ROCEK, J.; GILBERT, M.E.; BROADBENT, E.N. Brazil nut (Bertholletia excelsa, Lecythidaceae) regeneration in logging gaps in the Peruvian Amazon. International Journal of Forestry Research, v.1, p.1-8, 2014.

SALOMÃO, R.P. Densidade, estrutura, distribuição espacial de castanheira-do-brasil (Bertholletia excelsa H.\&B.) em dois platôs de floresta ombrófila densa na Amazônia setentrional brasileira. Boletim do Museu Paraense Emilio Goeldi, Belém, v.4,n.1,p.11-25, 2009.

SCOLES R.; GRIBEL R. Population structure of (Bertholletia excelsa, lecythidaceae) stands in two areas with different occupation histories in the Brazilian Amazon. Human Ecology, v.39, p.455-464, 2011.

SCOLES R.; GRIBEL R. The regeneration of brazil nut trees in relation to nut harvest intensity in the Trombetas River valley of Northern Amazonia, Brazil. Forest Ecology and Management, Amsterdam, v.265, p.71-81, 2012.

SCHÖNGART, J.; GRIBEL, R.; FONSECA-JUNIOR, S.F.; HAUGAASSEN, T. Age and growth patterns of Brazil nut trees (Bertholletia excelsa Bonpl.) in Amazônia, Brazil. Biotrópica, Washington, v.47, n.5, p.550-558, 2015.

EMBRAPA. Disponível em: https://www.senar-ap.org.br/noticia/pesquisa-aponta-queda-de-70-na-producao-decastanha-da-amazonia. Acesso em 29/05/2018.

SOUZA, A.L.; SOARES, C.P.B. Florestas nativas: estrutura, dinámica e manejo. Viçosa, MG: Editora da UFV, 2013, 322 p.

STAUDHAMMER, C.L.; WADT, L.H.O.; KAINER, K.A. Trade off in basal area growth and reproduction shift over the lifetime of a long-lived tropical species. Oecologia, Berlim, v.173, p.45-57, 2013.

THOMAS, E.; CAICEDO, C.A.; McMICHAEL, C.H.; CORVERA, R.; LOO, J. Uncovering spatial patterns in the natural and human history of brazil nut (Bertholletia excelsa) across the Amazon basin. Journal of Biogeography, Oxford, v.42, p.1367-1382, 2015.

TONINI, H. Amostragem para a estimativa de produção de sementes de castanheira-do-brasil em floresta nativa. Pesquisa Agropecuária Brasileira, Brasília, v.48, n.5, p.519-527, maio, 2013.

TONINI, H.; PEDROZO, C. A. Variações anuais na produção de frutos e sementes de castanheira-do-brasil (Bertholletia excelsa Humb.\&Bonpl., Lecythidaceae) em florestas nativas de Roraima. Revista Árvore,Viçosa, v.38, n.1, p. 2014. 
ZUIDEMA P.A; BOOT R.G.A. Demography of the brazil nut tree (Bertholletia excelsa) in the bolivian amazon: Impact of seed extraction on recruitment and population dynamics. Journal of Tropical Ecology, Cambridge, v.18, n.1, p.1-31, 2002.

ZUIDEMA, P.A. Demography and management of the Brazil nut tree (Bertholletia excelsa). Riberalta: PROMAB, 2003.

WADT, L.H.O.; KAINER, K.A.; GOMES-SILVA, D.A.P. Population structure and nut yield of a Bertholletia excelsa stand in Southwestern Amazonia. Forest Ecology and Management, Amsterdam, v.211, p.371-384, 2005

WADT, L.H.O.; KAINER, K.A.; STAUDHAMMER, C.L; SERRANO, R.O.P. Sustainable forest use in Brasilian extractive reserves: natural regeneration of Brazil nut in exploited populations. Biological Conservation, v.141, p.332-346, 2008.

WADT, L.H.O.; FAUSTINO, C.L.; STAUDHAMMER, C.L.; KAINER, K.A.; EVANGELISTA, J.S. Primary and secondary dispersal of Bertholletia excelsa: Implications for sustainable harvests. Forest Ecology and Management, Amsterdam, v.415-416, p.98-105, 2018. 